\title{
CHILDREN SOCIAL ATTRIBUTION BASED ON GENDER PERSPECTIVE
}

\author{
Refika Mastanora \\ IAIN Batusangkar \\ Email: \\ refikamastanora@iainbatusangkar.ac.id

\section{Rudi Pranata} \\ SMA N 2 Lintau Buo \\ Email: rudipranata02@gmail.com

\section{Oktri Permata Lani} \\ IAIN Batusangkar \\ Email: \\ oktripermatalani@iainbatusangkar.ac.id
}

\begin{abstract}
Social attribution can appear spontaneously or through long considerations and thinking process. Factors influencing attribution is the attribution style; planned and unplanned attribution. This kind of behavior can arise due to emotional factors. Meanwhile, children's social attributions arise because of stereotypes or labeling that have been attached to society, thus it has an impact on children's understanding of gender since they were born. The existence of social construction regarding gender roles cannot be separated from how the paradigm views the labeling of the characteristics of women and men is. In children, this social attribution usually occurs because of the stereotype of gender roles taught to children. This stereotype is a labeling that begins based on the perception or point of view of a person. While gender role stereotypes are part of the discussion about gender "sex", namely social expectations that define how men and women think, feel, and act, which are part of the product of the stereotype itself.
\end{abstract}

Keywords: Social attribution, Children, Gender

\section{PENDAHULUAN:}

Dalam beberapa pembahasan sering disebutkan bahwa kehidupan social merupakan susunan yang kompleks yang mengandung banyak informasi yang tidak jelas hubungannya natara satu dengan lainnya. Untuk menyederhanakan proses pengolahan informasi maka di perlukan komunikasi social yang efisien, dengan demikian kita aka menjadi kendali untuk mewujudkan lingkungan yang baik. Selain itu, terdapat proses yang sebenarnya tidak kalah pentingnya yaitu memahami faktor yang menjadi penyebab suatu kejadian, ini biasanya disebut dengan causal attribution. Perubahan perilaku ini pemicunya dapat berasal dari motivasi dibalik perilaku-perilaku dan cara seseorang menarik kesimpulan.

Dalam beberapa penelitian, Unger \& Crowford (1992) menyebutkan bahwa teori atribusi merupakan bagian dari Psikologi social yang bersibuk diri dengan cara seseorang menerangkan penyebab dari perilaku sendiri dan orang lain. 
Menurut Baron \& Byrne (1997) dalam Abdul Agus (2014), atribusi sosial adalah proses yang kita lakukan untuk mencari penyebab dari perilaku orang sehingga kita akan mendapatkan tambahan pengetahuan mengenai karakteristik dari orang lain. Atribusi social ini akan muncul saat adanya interaksi komunikasi antar personal. Begitupula perilaku anak, anak sejak lahir belajar dari interaksi dilingkungan tempat ia tinggal. Jika anak dibesarkan dengan kasih saying, anak akan tahu cara menghargai, jika anak dibesarkan dengan kekerasan, maka anak akan tahu cara membangkang. Dalam beberapa jurnal dan literasi keilmuan psikologi social banyak yang membicarakat tentang teori-teori yang mengupas perkembangan anak dari sudit pandang beberapa ahli, teori tersebut mempengaruhi cara pandang dan cara bersikap terhadap berbagai perilaku yang muncul dari anak, dan mengapa anak suka berbohong.

Salah satu contohnya disaatkan anak mendapatkan nilai ujian yang tidak sesuai harapan, biasanya ia akan mencari-cari faktor penyebab yang menjelaskan kejadian tersebut. Kemudian dengan pemrosesan kognitif yang dilakukan, sering kali muncul streotype bahwa anak perempuan biasanya lebih mendominasi dalam hal prestasi akademik disekolah, sedangkan anak laki-laki cenderung ugal-ugalan dan membolos saat jam pelajaran di kelas.

Atribusi social bisa juga berlangsung secara spontan atau melalui pertimbangan dan proses berfikir yang panjang. Faktor motivasi, potensi resiko, kemampuan atau keterlibatan personal sangat berpengaruh apakah atribusi tersebut dilakukan dengan pertimbangan secara mendalam ataupun spontan. Untuk halhal yang dinilai tidak terlalu penting, atribusi social kadang hanya didasarkan dari stereotype kesan pertama, atau yang sering disebut shortcut mental lainnya. Faktor lainnya yang berpengaruh pada atribusi adalah gaya atribusi. Sebagian orang memang memiliki gaya atribusi yang sifatnya spontan. Ia mengatribusikan banyal hal secara spontan. Sebaliknya, ada juga yang gaya atribusinya penuh pertimbangan. Orang yang menggunakan gaya atribusi penuh biasanya melakukan pertimbangan memikirkan dengan seksana setiap atribusi yang dilakukan.

Poin terakhir, atribusi social ini dilakukan secara terencana dan tidak terencana. Perilaku seperti ini bisa saja muncul karena faktor emosi, misalnya ketika seseorang dilanda masalah atau musibah, kadang sering diatribusikan sebagai yang tidak terencana dan pelaku tidak memiliki terhadap control terhadap perilakunya.

\section{PEMBAHASAN}

Atribusi social adalah proses yang kita lakukan dalam mencari penyebab dari perilaku orang sehingga kita dapat mengetahui karakteristik stabil dari orang tersebut. Perilaku yang sifatnya kompleks di reduksi sedemikian rupa menjadi representasi yang bersifat abstrak. Atribusi merupakan proses yang cenderung subjektif. Atribusi boleh saja didasarkan informasi yang bersifat objektif sehingga harus mengalami reduksi dan simplikasi. Dalam melakukan atribusi biasanya kita menganggap cukup dengan informasi, sesuai dengan pemahaman kita, kita sering merasa tidak perlu untuk memvalidasi kembali kecukupan dan kebenaran informasi yang kita dapat. Berdasarkan informasi yang 
didapat, kita tentu melakukan penilaian yang normative yang tentu saja dipengaruhi oleh penilaian subjektif, dalam hal ini perbedaan individual akan berpengaruh terhadap varietas atribusi yang dilakukan.

Atribusi merupakan asumsi-asumsi terkait mengapa orang berperilaku tertentu. Percaya tentang perbedaan penyebab ini mengarah kepada perbedaan harapan terhadap laki-laki dan perempuan. Melalui atribusi inilah biasanya sikap streotip muncul dan berperan sebagai mekanisme kontrol sosial. Perbedaan atribusi terhadap laki-laki dan perempuan ini hadir pada area perilaku yang luas dan bervariasi yang membantu dalam membentuk dasar pendiskriminasian terhadap lakilaki dan perempuan (Unger dan Crowford, 1992).

Perkembangan anak mengikuti prinsip atau hukum tertentu yang berlaku umum pada setiap anak, hukum tempo perkembangan menuntun orang tua untuk tidak panik terkait dengan kemampuan berbicara anak yang kurang dari anak orang lain. Adakalanya perkembangan tidak berjalan dengan mulus, karena itu gejala-gejala kejiwaan bisa di selidiki dengan beberapa metode untuk mengetahui sebab-akibat. Salah satunya atribusi social anak berdasarkan perspektif gender. Anak dari dalam kandungan sudah mulai mengenal lingkungan sosialnya, dalam agama islam biasanya orang tua dianjurkan untuk banyak mengaji guna membentuk arah kepribadian si anak. Jika anak laki-laki biasanya dibacakan surat Yusuf supaya anak yang lahir diharapkan bisa memiliki keteladan seperti Nabi Yusuf yang salah satunya ketampanan dan kesabaran, atau sang Ibu mengenakan nama Muhammad jika bayi dalam kandungannya berjenis laki-laki, begitupula jika janin yang dikandung berjenis perempuan, maka sang ibu sering membacakan surat Maryam, serta nama yang disematkan adalah nama-nama khalifah dari kaum perempuan, disamping itu perlengkapan bayi dan permainan yang dipersiapkan adalah yang sesuai dengan yang ada didalam kandungan, sehingga sejak itulah terbentuk karakter sang anak.

Kajian tentang atribusi pada awalnya dilakukan Heider, dalam tradisi fenomenologi pertanyaan yang diajukan adalah bagaimana kita melakukan kontak dengan dunia nyata jika pikiran indrawi. Dalam situasi social, kita secara konstan berusaha untuk memahami orang lain, dan kemudian menarik kesimpulan atas apa yang mendasari atau melatarbelakangi perilaku tersebut. Menurut Dyakisni (2006:52) Atribusi merupakan proses yang dilakukan untuk mencari sebuah jawaban atau pertanyaan mengapa orang berperilaku. Proses atribusi ini sangat berguna untuk membantu pemahaman kita akan penyebab perilaku dan merupakan mediator yang penting bagi reaksi kita terhadap dunia social.

Atribusi merupakan suatu proses penilaian tentang penyebab, yang dilakukan individu setiap hari terhadap berbagai peristiwa, dengan atau tanpa disadari. Atribusi terdiri dari 3 dimensi yaitu; 1) lokasi penyebab, masalah pokok yang paling umum dalam persepsi sebab akibat adalah apakah suatu peristiwa atau tindakan tertentu disebabkan oleh keadaan internal (hal ini disebut sebagai atribusi internal) atau kekuatan eksternal (atribusi eksternal); 2) stabilitas, dimensi sebab akibat yang 
kedua adalah berkaitan dengan pertanyaan apakah penyebab dari suatu peristiwa atau perilaku tertentu itu stabil atau tidak stabil. Dengan kata lain stabilitas mengandung maknaseberapa permanen atau berubahubahnya suatu sebab; 3) pengendalian, dimensi ini berkaitan dengan pertanyaan apakah suatu penyebab dapat dikendalikan atau tidak dapat dikendalikan oleh seorang individu. (dalam Nurhayati,2005:3-4)

Ada dua macam asumsi tentang tujuan proses atribusi :

a) Proses atribusi mempunyai tujuan untuk memperoleh pemahaman terhadap dunia. Kesimpulan-kesimpulan dibuat untuk memahami lingkungan dan memprediksi kejadian-kejadian di masa yang akan dating

b) Proses atribusi yang dipelajari secara alami dan mempunyai tujuan untuk menjelaskan tindakantindakannya sendiri serta berusaha untuk mengendalikan tindakan-tindakan orang lain yang mempunyai hubungan interpersonal dekat dengan dirinya.

Model-model proses atribusi

a. Model Heider, yaitu analisa secara sistematik tentang bagaimana orang menginterprestasikan sebab perilaku orang lain pada awalnya dilakukan oleh Heider (dalam Hudaniah, 2006:53). Heider mengemukakan bahwa masingmasingdari kita dalam interaksi sehari-hari dengan orang lain akan bertingkah laku mirip seorang ilmuwan. Dalam menginterprestasi perilaku orang lain, orang menggunakan prinsip-prinsip kausal yang naluriah dan commonsensepsikologi dalam memutuskan apakah perilaku orang lain diatribusikan pada faktor disposisi internalatau tidak.Menurut model Heider, perilaku seseorang dapat disimpulkan disebabkan oleh kekuatankekuatan internal (termasuk disposisi). Kekuatan-kekuatan lingkungan terdiri dari faktor situasi yang menekan, sehingga memunculkan perilaku tertentu. Kekuatan-kekuatan internal (personal forces) dilihat sebagai hasil dari kemampuan (ability), powerdan usaha yang ditunjukkan seseorang.

b. Teori inferensi korespondensi, dalam ini Edward jones dan koleganya (dalam Hudaniah, 2006:53) mempelajari pengaruh kekuatan disposisional dan lingkungan pada atribusi kausal. Mereka menganalisa kondisikondisi yang memunculkan atribusi disposisional, atau apa yang mereka sebut dengan istilah inferensi korespodensi, yaitu kasus dimana 15 pengamat memutuskan bahwa disposisi khusus dari actor (persin stimuli) adalah penjelasan yang cukup masuk akal bagi perilaku atau tindakan actor.

c. Teori Kelley atribusi kausal, yaitu memfokuskan diri pada pertanyaan apakah perilaku seseorang berasal dari faktor internal atau eksternal. Untuk menjawab pertanyaan ini ada beberapa aspek yang mesti dipertimbangkan, yaitu consensus, konsistensi, dan distingsi. Ketika terdapat dua atau lebih kemungkinan faktor penyebab suatu perilaku, kita cenderung untuk mengabaikan peran salah satu dari antaranya hal ini dikenal sebagai 
suatu efek discounting. Ketika suatu penyebab yang memfasilitasi munculnya suatu perilaku dan penyebab yang mengeliminasi terjadinya suatu perilaku, keduanya sama-sama hadir namun perilaku tersebut tetap muncul, kita member nilai tambah pada faktor yang memfasilitasi lahirnya perilaku tadi, hal ini disebut augmenting.

Kita kadang mengartikan artibusi ini secara keliru, salah satunya tipe kesalahan yang sering terjadi adalah bias korespondensi, yaitu kecendrungan untuk menjelaskan perilaku seseorang sebagai cerminan dari disposisinya, padahal faktor situasional sering muncul pada perubahan perilaku seseorang. Kecendrungan ini lebih kuat terjadi di masyarakat dengan latar budaya barat. Dua jenis kesalahan atribusi lainnya adalah efek pengamat, yaitu kecendrungan untuk mengatribusi perilaku lebih pada faktor eksternal dan internal.

Teori atribusi menyatakan bahwa setelah mengalami peristiwa yang negatif atau menyakitkan, orangorang membuat atribusi untuk memudahkan penyesuaian, karena atribusi membantu mereka merasa bahwa mereka dapat mengontrol lingkungan (Kelley, dalam Tennen dkk, 1986) dan reaksi mereka sendiri (Taylor, dalam Tennen dkk, 1986). Atribusi terhadap peristiwa-peristiwa negatif tersebut dipercaya memiliki arti penting dalam memprediksi strategi menghadapi masalah yang digunakan individu (Major, dkk, 1985). Menurut Follette dan Jacobson (1987), orang yang mengatribusikan peristiwa yang dialaminya pada sesuatu yang di luar dirinya akan memiliki cara yang berbeda untuk menghadapi peristiwa tersebut dibandingkan dengan orang yang tipe atribusinya internal. Misalnya individu yang tipe atribusinya internal, stabil dan global akan cenderung menerima dirinya dalam kondisi tidak berdaya dan tanpa harapan (Metalsky, dkk, 1987).

Pada anak biasanya atribusi social ini terjadi karena streotip peran gender yang diajar kepada anak yang terjadi sejak lahir. Streotip ini merupakan pelabelan yang diawali berdasarkan persepsi/ sudut pandang tentang seseorang. Sedangkan streotip peran gender adalah bagian pembahasan tentang gender 'jenis kelamin", yakni ekspektasi social yang merumuskan bagaiaman pria dan wanita berfikir, merasa, dan berbuat, yang merupakan bagian produk dari streotip itu sendiri. Maka peran gender merupakan hasil dari pelabelan yang yang akhirnya menjadi perngharapan social yang sulit untuk diubah.

Perempuan dikontruksikan sebagai makhluk yang perlu dilindungi, kurang mandiri, tidak rasional, hanya mengandalkan perasaan, dan lain-lain. Konsekuensinya, muncul batasanbatasan yang menempatkan perempuan pada ruang penuh dengan aturan baku yang perlu dijalankan. Padahal, banyak sisi positif dari perempuan yang membedakannya dengan laki-laki dan jarang diekspos. Yaitu watak dan karakter. Seperti kemampuan pengendalian diri, kekuatan emosi, kepekaan sosial, Konsep pembakuan peran gender yang mengotak-kotakkan peran laki-laki atau suami dan perempuan atau istri ini hanya memungkinkan perempuan berperan di wilayah domestik yakni sebagai pengurus rumah tangga sementara lakilaki di wilayah publik sebagai kepala 
keluarga dan pencari nafkah utama. Dengan begitu dapat disimpulkan atribusi social anak terbentuk berdasarkan streotip/pelabelan yang diberikan orang tua berdasarkan gender anak. (Anggono 2008)

\section{KESIMPULAN}

Anak dari dalam kandungan sudah mulai mengenal lingkungan sosialnya, dalam agama islam biasanya orang tua dianjurkan untuk banyak mengaji guna membentuk arah kepribadian si anak. Jika anak laki-laki biasanya dibacakan surat Yusuf supaya anak yang lahir diharapkan bisa memiliki keteladan seperti Nabi Yusuf yang salah satunya ketampanan dan kesabaran, atau sang Ibu mengenakan nama Muhammad jika bayi dalam kandungannya berjenis laki-laki, begitupula jika janin yang dikandung berjenis perempuan, maka sang ibu sering membacakan surat Maryam, serta nama yang disematkan adalah nama-nama khalifah dari kaum perempuan, disamping itu perlengkapan bayi dan permainan yang dipersiapkan adalah yang sesuai dengan yang ada didalam kandungan, sehingga sejak itulah terbentuk karakter sang anak.

Pada anak biasanya atribusi social ini terjadi karena streotip peran gender yang diajar kepada anak yang terjadi sejak lahir. Streotip ini merupakan pelabelan yang diawali berdasarkan persepsi/ sudut pandang tentang seseorang. Sedangkan streotip peran gender adalah bagian pembahasan tentang gender "jenis kelamin", yakni ekspektasi social yang merumuskan bagaiaman pria dan wanita berfikir, merasa, dan berbuat, yang merupakan bagian prduk dari streotip itu sendiri. Maka peran gender merupakan hasil dari pelabelan yang yang akhirnya menjadi perngharapan social yang sulit untuk diubah.

Berdasarkan data-data yang diperoleh, tindak pidana pada anak disebabkan karena adanya motivasi intrinsik, yaitu inteligensi rendah, kontrol diri rendah, usia, jenis kelamin, dan identitas yang keliru (psikogenis), dan motivasi ekstrinsik meliputi keluarga, peer group, lingkungan sekitar (sosiogenis), kelas sosial ekonomi, dan pengaruh mass media. Narapidana anak selama menjalani pembinaan mengalami proses pengendalian (Controllability) antara orientasi penyebab (locus of causality) dan aspek kestabilan (stability), dalam pelaksanaan pembinaan narapidana anak memiliki kesamaan perilaku dengan narapidana lain (konsensus tinggi), berperilaku terhadap stimulus yang sama dalam situasi yang berbeda (konsistensi tinggi) dan berperilaku terhadap situasi yang berbeda-beda (distingsi tinggi), serta adanya kepercayaan, representasi sosial, dan perilaku memilih.

Dalam Jurnal Psikologi UGM. Hipotesis yang diajukan adalah (1) ada hubungan positif antara atribusi kekerasan dalam rumah tangga, kesadaran terhadap kesetaraan gender, dan strategi menghadapi masalah yang berorientasi pada masalah (SMM-M), dan (2) ada hubungan negatif antara atribusi kekerasan dalam rumah tangga, kesadaran terhadap kesetaraan gender, dan strategi menghadapi masalah yang berorientasi pada emosi (SMM-E). 
Sebanyak 45 orang perempuan korban kekerasan dalam rumah tangga berpartisipasi dalam penelitian ini. Penelitian ini menggunakan skala psikologis yang meliputi skala atribusi kekerasan dalam rumah tangga, skala kesadaran terhadap kesetaraan gender, dan skala strategi menghadapi masalah. Data yang terkumpul dianalisis menggunakan analisis regresi dengan metode stepwise.Hasil penelitian ini memperlihatkan (1) ada hubungan positif yang sangat signifikan antara atribusi kekerasan kekerasan dalam rumah tangga dan kesadaran terhadap kesetaraan gender dengan strategi menghadapi masalah yang berorientasi pada masalah (SMM-M). (2) tidak ada hubungan yang signifikan antara atribusi kekerasan kekerasan dalam rumah tangga dan kesadaran terhadap kesetaraan gender dengan strategi menghadapi masalah yang berorientasi pada emosi (SMM-E). Namun demikian dalam pengujian hipotesis kedua ini ditemukan bahwa kesadaran terhadap kesetaraan gender secara signifikan mampu menjadi prediktor bagi strategi menghadapi masalah yang berorientasi pada emosi (SMM-E) ; (3) para perempuan korban kekerasan dalam rumah tangga menggunakan SMM- M dan SMM-E sekaligus untuk mengatasi masalahnya.

\section{DAFTAR PUSTAKA}

Abdul, Agus. 2014, Psikologi Sosial : Intergrasi Pegetahuan wahyu dan pengetahuan empiric. Jakarta : PT Rajagrafindo Persada.

Anggono, A. T. (2008). Atribusi sosial narapidana anak di Lembaga Pemasyarakatan Kelas IIA Sragen, Universitas Muhammadiyah Surakarta.

NN,. 2008. Makalah "Elimination of
Gender Stereotypes: Mission (Im)Possible?" dipresentasikan di Lobi European Women's.

Nuraini, 2008, Menyoal Pendidikan Berbasis Gender, dalam http://www.majalahopini.co.cc , diakses pada tanggal 16 Mei 2021.

Rohmah, Siti. 2010. Atribusi Kekerasan dalam Rumah Tangga, Kesadaran terhadap kesetaraan gender dan strategi menghadapi masalah pada perempuan korban kekerasan dalam rumah tangga.

Santrock, J.W. 2008. Psikologi Pendidikan. Jakarta: Kencana, 2008.

Schneider, David J., The Psychology Of Stereotyping, (New York : The Guilford Press, 2004).

Secord \& Backman, Social psychology. (New York: McGraw-Hill, 1964).

Widarmanto, $\quad \mathrm{T}, \quad$ Pendidikan yang Berperspektif Gender, http://203.130.242.190/artikel/ 2289.shtml, diakses pada tanggal 20 Mei 2021.

Zaduqisti, Esti.2009. Stereotipe Peran Gender Bagi Pendidikan Anak Muzawah, Vol 1,No. 1 Januari-Juni 2009. 
Agenda, Volume 3 Nomor 1, Juni 2021 